\title{
Risk assessment and rate of readmission within 30 days of discharge after hospitalization for acute exacerbation of chronic obstructive pulmonary disease
}

\author{
Celalettin YILMAZ $^{1}(\mathrm{ID})$ \\ Serir ÖZKAN ${ }^{1,2}$ (ID) \\ Onur Fevzi ERER ${ }^{1}$ (ID)
}

\author{
${ }^{1}$ Clinic of Chest Diseases, Izmir Dr. Suat Seren Training and Research \\ Hospital for Thoracic Medicine and Sugery, University of Health Sciences, \\ Izmir, Turkey \\ ${ }^{1}$ Sağlık Bilimleri Üniversitesi, İzmir Dr. Suat Seren Göğüs Hastalıkları ve \\ Cerrahisi Ĕgitim ve Araştırma Hastanesi, Göğüs Hastalıkları Kliniği, \\ izmir, Türkiye \\ 2 Department of Chest Diseases, University of Health Sciences \\ Faculty of Medicine, Izmir, Turkey \\ ${ }^{2}$ Sağlık Bilimleri Üniversitesi İzmir Tıp Fakültesi, Göğüs Hastalıkları \\ Anabilim Dalı, İzmir, Türkiye
}

*This study was presented as a verbal presentation at the $18^{\text {th }}$ Annual Congress of the Turkish Thoracic Society.

Cite this article as: Yılmaz C, Özkan S, Erer OF. Risk assessment and rate of readmission within 30 days of discharge after hospitalization for acute exacerbation of chronic obstructive pulmonary disease. Tuberk Toraks 2021;69(3):328-337.

\section{Address for Correspondence (Yazışma Adresi)}

\section{Dr. Celalettin YILMAZ}

Clinic of Chest Diseases, Izmir Dr. Suat Seren Training and Research

Hospital for Thoracic Medicine and Sugery,

University of Health Sciences

IZMIR - TURKEY

e-mail: celalettinyilmaz35@gmail.com

CCopyright 2021 by Tuberculosis and Thorax.

Available on-line at www.tuberktoraks.org.com

\section{ABSTRACT}

Risk assessment and rate of readmission within 30 days of discharge after hospitalization for acute exacerbation of chronic obstructive pulmonary disease

Introduction: Patients with chronic obstructive pulmonary disease (COPD) hospitalized for an exacerbation are at risk of early readmission for any reason within 30 days of discharge. Understanding the frequency and risk factors related to readmission can provide valuable input for the development of readmission reduction strategies. The aim of this study was to investigate the frequency, specific risk factors and the cost analysis of early readmission for any reason within 30 days after discharge of the patients hospitalized for acute exacerbation of chronic obstructive pulmonary disease (AECOPD).

Materials and Methods: In a prospective comparative case series study, 110 patients over 40 years of age who were hospitalized with AECOPD were included. The frequency of readmissions within 30 days of discharge after hospitalization for AECOPD was investigated. Those who were admitted to any hospital for any reason within 30 days after discharge were classified as the readmission group. Whereas nonhospitalized patients were defined as the nonreadmission group. Demographic, clinical, therapeutic, laboratory and financial data of the groups were evaluated. 
Results: Thirty-four (30.9\%) COPD patients were readmitted during the first 30 days post index hospitalization. In multivariate analysis, the best predictors of early readmission were the low forced expiratory volume in one second (FEV 1$)$ predicted \% (FEV $\%$ ) (OR= $0.961, \% 95 \mathrm{Cl} 0.927-0.997 p=0.034)$ and COPD diagnosis time $(O R=0.908, \% 95 \mathrm{Cl} 0.838-0.983 p=0.017)$. Mean length of stay of the second hospitalization was longer than both the readmitted and nonreadmitted groups (8.3, 8.1 and 7.8 days respectively). While mean cost of second hospitalization was $1189 \$$, mean cost of index hospitalization of the readmission group was $794 \$$ and that of index hospitalization of nonreadmission group was $582 \$$.

Conclusion: The frequency of readmissions within 30 days after discharge of the patients hospitalized for AECOPD are common and costly. Low FEV, percentage and lower diagnosis time were found to be significant predictors for readmission within 30 days of the index hospitalization.

Key words: Chronic obstructive pulmonary disease; hospital readmissions; risk factors; exacerbations

ÖZ

Alevlenme nedeniyle hastaneye yatan kronik obstrüktif akciğer hastalarında taburcu olduktan sonraki 30 gün içerisinde hastaneye yeniden yatış risk faktörleri

Giriş: Alevlenme nedeniyle hastaneye yatırılan kronik obstrüktif akciğer hastaları (KOAH), taburcu olduktan sonraki 30 gün içinde herhangi bir nedenle erken hastaneye geri yatış riski alındadır. Bu geri yatışlarla ilgili sıklık ve risk faktörlerinin anlaşılması, geri yatışları azaltmada bize rehber olabilmektedir. Bu çalışmanın amacı, KOAH alevlenme nedeniyle hastaneye yatırılan hastaların taburcu olduktan sonraki 30 gün içinde herhangi bir nedenle hastaneye geri yatış sıklı̆̆ını, spesifik risk faktörlerini ve maliyet analizini araştırmaktrr.

Materyal ve Metod: Prospektif olan bu çalışmaya 40 yaş üstü KOAH alevlenme nedeniyle hastaneye yatırılan 110 hasta dahil edilmiştir. Hastalar taburcu olduktan sonraki 30 gün içinde yeniden hastaneye yatış durumuna göre iki gruba ayrılmıştır. Taburculuk sonrası 30 gün içinde tekrar hastane yatışı olanlar geri kabulü olan ("readmission") grup, tekrar hastaneye yatmayanlar geri kabul olmayan ("non-readmission") grup olarak tanımlanmışır. Grupların demografik, klinik, tedavi, laboratuvar ve finansal verileri değerlendirilmiştir.

Bulgular: Otuz dört $(\% 30,9)$ KOAH hastasının taburculuk sonrası 30 gün içinde tekrar hastaneye geri yatışı olmuştur. Yapılan çok değişkenli analizde, erken geri yatışların en iyi göstergesi düşük $F E V_{1} \%(O R=0,961, \% 95$ GA 0,927-0,997 p=0,034) ve KOAH tanı süresidir $(O R=0,908, \% 95$ GA 0,838-0,983 p=0,017). Ikinci hastanede yatışın ortalama süresi, geri kabulü olan grubun indeks yatışı ile geri kabulü olmayan grubun indeks yatışına göre daha uzun bulunmuştur (sırasıyla 8,3, 8,1 ve 7,8 gün). Tekrar hastaneye yatış maliyeti ortalama $1189 \$$ iken, bu grubun indeks yatışındaki ortalama yatış maliyeti $794 \$$ ve geri kabul olmayan grubun indeks hastane yatış maliyeti $582 \$$ 'dır.

Sonuç: KOAH Alevlenme nedeniyle yatarak tedavi olan hastalarda taburculuk sonrası 30 gün içinde tekrar hastaneye yatma durumu sıktır ve maliyetlidir. Düşük FEV 1 yüzdesi ve KOAH tanı süresinin kısalığı, taburculuk sonrası 30 gün içinde yeniden hastane geri kabulü için önemli bir belirteç olarak bulunmuştur.

Anahtar kelimeler: Kronik obstrüktif akciğer hastalı̆̆ı; hastane geri yatışı; risk faktörleri; alevlenmeler

\section{INTRODUCTION}

Acute exacerbation of chronic obstructive pulmonary disease (AECOPD) is known to cause progression of disease, increased risk of morbidity and mortality, accelerated decline in lung function and deterioration of quality of life. The decline in lung function of COPD patients also tends to be associated with recurrent acute exacerbations. The majority of exacerbation are treated at the outpatient clinic while more severe patients require hospitalizations and readmissions (1).

COPD has a significant economic burden, and more than half of this cost is due to hospitalizations. Especially exacerbation and hospitalization constitute the socioeconomic burden of the disease directly (medical treatment, hospital cost) and indirectly (loss of work force). Moreover, a patient with hospitalized AECOPD is at risk of early readmission for any reason within 30 days of discharge. Heart failure and COPD have the highest 30-day readmission rates. $(1,4)$. Since "early readmissions" have significantly both clinical and economic impact, it is important to know the frequency and risk factors of readmissions within 30 days of discharge after a hospitalization for AECOPD.

The aim of this study was to investigate the frequency, specific risk factors and the cost analysis of early readmission for any reason within 30 days after the discharge of patients hospitalized for AECOPD.

\section{MATERIALS and METHODS}

This single-center, prospective comparative case series study was approved by the local institutional 
review board (approval number: 369 and date: 03.01.2014) and was carried out in accordance with the principles of the Helsinki Declaration. Written informed consent was obtained from all patients enrolled.

\section{Study Population}

The study included 110 consecutive patients over 40 years of age who were hospitalized with AECOPD between January 1 and July 31, 2014 at the University of Health Sciences Izmir Dr. Suat Seren Research and Training Hospital for Thoracic Medicine and Surgery, Third Clinic. The patients who died during index hospitalization were excluded. COPD exacerbation management and discharge criteria were performed by the same physicians working in the clinic.

\section{Primary Outcome}

Readmission rate from all-cause within 30 days after the discharge from index hospitalization for AECOPD.

\section{Secondary Outcomes}

To describe patient characteristics and risk factors associated with early hospital readmission for COPD and to do cost analysis.

\section{Early Readmission and Study Design}

Early readmission is hospitalization for any reason occurring within 30 days after discharge from index admission for AECOPD, with the date of discharge counted as day 0 . Those who were admitted to any hospital for any reason within 30 days after discharge were classified as the readmission group. Whereas non-hospitalized patients were defined as the non-readmission group. The flow chart of the patient registration process and the study design is given in Figure 1.

\section{Variables}

Research Database contains the following components and patient groups were compared in terms of these:

1. Demographics: Age, sex and economic (household income) characteristics

2. Type and numbers of comorbid conditions

3. Clinical characteristics; COPD diagnosis time, hospitalization within one month before index admission, body mass index (BMI), smoking status,
4. Therapeutic characteristics; regular inhaler therapy (any short-acting bronchodilator [SABA], long-acting beta agonist [LABA], long-acting muscarinic antagonist [LAMA], or inhaled corticosteroid [ICS]) within 90 days before index hospitalization, systemic corticosteroid use during index hospitalization, use of long-term oxygen therapy [LTOT] and/or bilevel positive airway pressure [BPAP] or continuous positive airway pressure [CPAP] therapy, inhaler medication training, influenza and/or pneumococcal vaccination status within a year before index hospitalization.

5. Laboratory characteristic; blood eosinophil cell count (cut-off level $\geq 2 \%$ of total white blood cell count on corticosteroid-free time during the index hospitalization), gas analysis variables (arterial blood gases were assessed at rest during room air breathing): Partial arterial carbon dioxide pressure $\left(\mathrm{pCO}_{2}\right)$, partial arterial oxygen pressure $\left(\mathrm{pO}_{2}\right)$ and functional finding from most recent spirometry prior to index hospitalization (forced expiratory volume in one second $\left[\mathrm{FEV}_{1}\right]$ predicted \%).

6. Others; length of stay (LOS) as day during hospitalization, rehospitalization places and diagnoses, length of readmission stay and hospitalization costs billed to the social insurance institution.

The above information was recorded in the standard case report form. All patients underwent the validated Turkish version of Saint-George Respiratory Questionnaire (SQRQ) and COPD Assessment Test (CAT) during index admissions.

The duration and cost analysis of readmissions within one month after discharge was obtained from the records of the hospital information processing system. The records of the readmissions to another hospital were received from the Social Insurance Institution.

Flowchart of patient enrollment process and study design are shown in Figure 1.

\section{Statistical Analysis}

Statistics package program was used in the analysis. Mean, one of the measures of central tendency, was used in continuous variables. In the analysis of continuous variables, dependent and independent sam- 


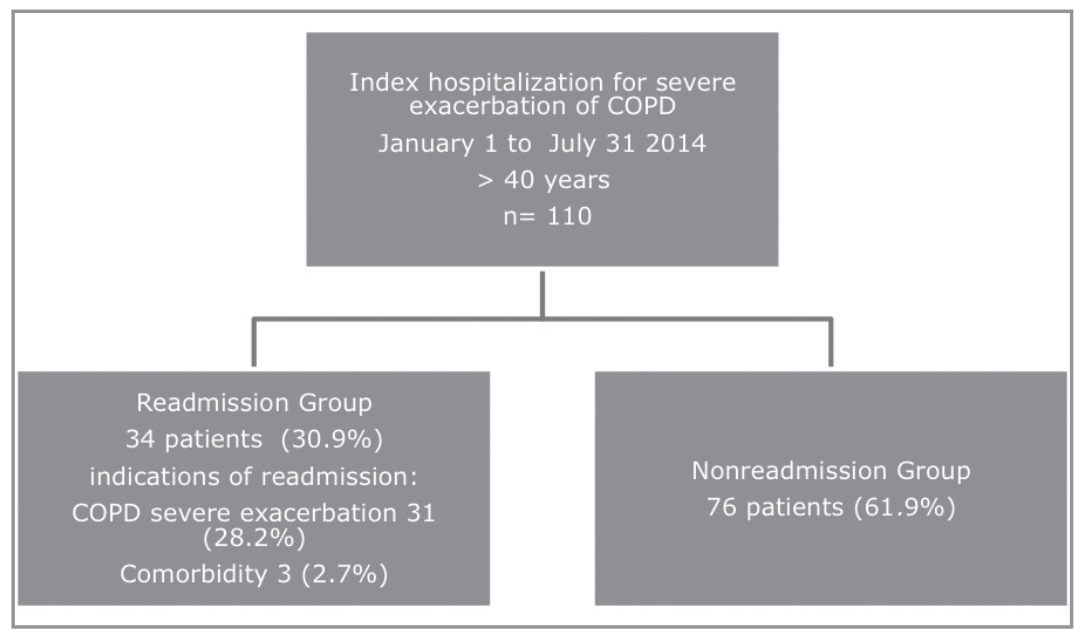

Figure 1. Flowchart of patient enrollement process and study design.

ples t-test, while evaluating discrete variables between groups, chi-square test was used. While Pearson correlation analysis was performed for variables that fit normal distribution, spearman correlation test was performed for those that did not. Logistic regression analysis was performed in terms of factors affecting dependent variables. A value of $p<0.05$ was accepted as the statistical significance limit.

\section{RESULTS}

A total of 110 hospitalized patients with AECOPD were included in the study, $90(81.8 \%)$ were males and $20(18.2 \%)$ were females. Thirty-four $(30.9 \%)$ patients were readmitted during the first 30 days post index hospitalization (Readmission Group). The leading cause of readmission in 31 patients was respiratory. Other reasons were comorbidities in three patients, which were acute coronary syndrome in two patients and heart failure in one patient. On the other hand, 76 (69.1\%) patients were not re-hospitalized in the first 30 days (Non-readmission Group). Baseline demographic characteristics were similar between the groups. The demographics and characteristics of the two groups are displayed in Table 1.

On univariate analysis, $\mathrm{FEV}_{1} \%$, COPD diagnosis time, SGRQ impacts score were found statistically significant between the groups. Mean FEV ${ }_{1}$ was $30 \%$ in the readmission group and $35.4 \%$ in the non-readmission group. $\mathrm{FEV}_{1}$ percentage was significantly lower in the readmission group $(p=0.039)$. Mean diagnosis time of COPD in the readmission group was 7.6 years and the other 10.6 years. COPD diagnosis time was significantly lower in the readmission group $(p=0.019)$. In the Readmission group, the SGRQ impact score was found to be significantly higher compared to the other group $(p=0.049)$. Household income in the readmission group was 459 , and in the non-readmission group, it was 537 \$ $(p=0.21)$. While the number of hospitalizations in the last year was 3.06 in the readmission group, it was 1.55 in the non-readmission group, the difference was not statistically significant $(p=0.08)$. There was no significant difference between the groups in terms of other factors (Table 1).

Multivariate analysis of the cohort revealed $\mathrm{FEV}_{1} \%$ $(\mathrm{OR}=0.961, \% 95 \mathrm{Cl} 0.927-0.997, \mathrm{p}=0.034)$ and COPD diagnosis time $(\mathrm{OR}=0.908, \% 95 \mathrm{Cl} 0.838$ $0.983, p=0.017$ ) as independently associated with increased readmission rates. SGRQ impact score was not an independent significant risk factor $(\mathrm{OR}=1.02$, \%95 Cl 0.996-1.044, $\mathrm{p}=0.104$ ).

Inhaler therapy (SABA, LAMA, LABA, ICS) usage within 90 days before index hospitalization was not significantly different between groups. Systemic steroid usage during index hospitalization, and LTOT administration within a year before index hospitalization were more in the readmission group, but the difference was not statistically significant. Therapeutic characteristics of the groups are given in Table 2.

Mean length of stay (LOS) of the second hospitalization was longer than both the readmitted and non-readmitted groups. The LOS for second hospitalization of the readmission group was 8.3 days. Mean LOS for index admissions was 8.1 days in the readmission group and 7.8 days in the non-readmission group. 
Rate and risk factors for re-hospitalizations after discharge in COPD patients

Table 1. Demographic, comorbid and clinical characteristics of the groups

\begin{tabular}{|c|c|c|c|}
\hline Total $n=110$ & $\begin{array}{l}\text { Readmission } \\
\text { Group } n=34\end{array}$ & $\begin{array}{l}\text { Non-readmission Group } \\
n=76\end{array}$ & $\mathbf{p}$ \\
\hline Male & $29(85.3)$ & $61(80.2)$ & 0.53 \\
\hline Age, years & $67.2 \pm 8.6$ & $68 \pm 9.7$ & 0.18 \\
\hline Smoking (pack-years) & $55.1 \pm 43.1$ & $52.8 \pm 31.9$ & 0.76 \\
\hline Household income $(\$)$ & $459 \pm 274$ & $537 \pm 316$ & 0.21 \\
\hline COPD diagnosis time, years & $7.6 \pm 5.2$ & $10.6 \pm 7.8$ & 0.01 \\
\hline Number of hospitalization in the last year & $3.06 \pm 4.8$ & $1.55 \pm 1.7$ & 0.08 \\
\hline $\mathrm{BMI}, \mathrm{kg} / \mathrm{m}^{2}$ & $23.3 \pm 6.7$ & $24.4 \pm 6.1$ & 0.39 \\
\hline Eosinofil count, $\geq 2 \%$ of total white blood cell count & $13(38.2)$ & $27(35.5)$ & 0.83 \\
\hline $\mathrm{FEV}_{1}, \%$ predicted & $30 \pm 10.8$ & $35.4 \pm 15.5$ & 0.03 \\
\hline $\mathrm{pO}_{2} \mathrm{~mm} / \mathrm{Hg}$ & $60.5 \pm 21$ & $57.8 \pm 16.8$ & 0.46 \\
\hline $\mathrm{pCO}_{2} \mathrm{~mm} / \mathrm{Hg}$ & $54.7 \pm 13.5$ & $51.3 \pm 17.5$ & 0.30 \\
\hline CAT Score & $26.3 \pm 7.8$ & $24.9 \pm 8.9$ & 0.41 \\
\hline $\mathrm{CAT} \geq 10$ & $31(91.2)$ & $69(90.8)$ & 10 \\
\hline $\mathrm{CAT}<10$ & $3(8.8)$ & $7(9.2)$ & 1.00 \\
\hline SGRQ Symptoms & $71.3 \pm 17.0$ & $70.4 \pm 19.5$ & 0.81 \\
\hline SGRQ Activities & $86.7 \pm 15.2$ & $81.2 \pm 19.9$ & 0.15 \\
\hline SGRQ Impact & $57.6 \pm 18.3$ & $49.6 \pm 20.7$ & 0.04 \\
\hline SGRQ Total & $68.8 \pm 15.3$ & $62.8 \pm 18.7$ & 0.10 \\
\hline \multicolumn{4}{|l|}{ Comorbidities } \\
\hline Hypertension & $7(20.5)$ & $25(32.8)$ & 0.19 \\
\hline Congestive heart failure & $6(17.6)$ & $13(17.1)$ & 0.94 \\
\hline Diabetes & $5(14.7)$ & $13(17.1)$ & 0.75 \\
\hline Coronary artery disease & $2(5.8)$ & $2(2.6)$ & 0.40 \\
\hline Malignancy & $1(2.9)$ & $1(1.3)$ & \\
\hline Chronic renal failure & $1(2.9)$ & 0 & \\
\hline No comorbid conditions & $22(64.7)$ & $44(57.9)$ & 0.35 \\
\hline One comorbidty & $7(20.6)$ & $16(21.1)$ & 1 \\
\hline Two comorbidities & $2(5.9)$ & $11(14.5)$ & 0.33 \\
\hline Three or more comorbidities & $3(8.8)$ & $5(6.6)$ & 0.70 \\
\hline
\end{tabular}

Table 2. Multivariate analysis results of the study

\begin{tabular}{|lccccc|}
\hline Variables $\quad$ Total $\mathbf{n = 1 1 0}$ & $\begin{array}{c}\text { Readmission } \\
\text { Group } \mathbf{n = 3 4}\end{array}$ & $\begin{array}{c}\text { Non-readmission } \\
\text { Group } \mathbf{n = 7 6}\end{array}$ & OR & \%95 Cl & $\mathbf{p}$ \\
\hline COPD diagnosis time, years & $7.6 \pm 5.2$ & $10.6 \pm 7.8$ & 0.908 & $0.838-0.983$ & $\mathbf{0 . 0 1}$ \\
FEV ${ }_{1}$ \% predicted & $30 \pm 10.8$ & $35.4 \pm 15.5$ & 0.961 & $0.927-0.997$ & $\mathbf{0 . 0 3}$ \\
SGRQ Impact Score & $57.6 \pm 18.3$ & $49.6 \pm 20.7$ & 0.02 & $0.996-1.044$ & 0.10 \\
\hline Data are presented as mean \pm SD. & & & & \\
\hline
\end{tabular}


Table 3. Therapeutic characteristics of the groups

\begin{tabular}{|c|c|c|c|}
\hline $\begin{array}{l}\text { Parameters } \\
\text { Total } n=110\end{array}$ & $\begin{array}{l}\text { Readmission } \\
\text { Group } n=34\end{array}$ & $\begin{array}{l}\text { Non-readmission } \\
\text { Group } n=76\end{array}$ & $\mathbf{p}$ \\
\hline \multicolumn{4}{|l|}{ Inhaler therapy* } \\
\hline ICS & $28(82.3)$ & $67(88.1)$ & 0.55 \\
\hline LAMA & $22(64.7)$ & $46(60.5)$ & 0.56 \\
\hline LABA & $25(73.5)$ & $63(82.8)$ & 0.26 \\
\hline SABA & $9(26.4)$ & $11(14.4)$ & 0.61 \\
\hline Systemic corticosteroid** & $16(47.1)$ & $30(39.5)$ & 0.53 \\
\hline Long-term oxygen therapy*** & $21(61.7)$ & $41(53.9)$ & 0.42 \\
\hline $\mathrm{NIMV}^{* * *}$ & $10(29.4)$ & $12(15.7)$ & 0.10 \\
\hline Pnemococcal vaccination $* * *$ & $7(20.5)$ & $13(17.1)$ & 0.66 \\
\hline Influenza vaccination $* * *$ & $12(35.3)$ & $30(39.5)$ & 0.68 \\
\hline Inhaler medication training ${ }^{* * *}$ & $27(79.4)$ & $59(77.6)$ & 0.83 \\
\hline \multicolumn{4}{|c|}{$\begin{array}{l}\text { Data are presented as } \mathrm{n}(\%) \\
\text { NIMV: Noninvasive mechanical ventilation. } \\
\text { * Within } 90 \text { days before index hospitalization. } \\
\text { ** During index hospitalization. } \\
\text { *** Within a year before index hospitalization. }\end{array}$} \\
\hline
\end{tabular}

Table 4. Length of stay (LOS) for admisison and readmission and cost analysis of the groups

\begin{tabular}{|c|c|c|c|}
\hline $\begin{array}{l}\text { Parameters } \\
\text { Total } n=\mathbf{1 1 0}\end{array}$ & $\begin{array}{l}\text { Readmission } \\
\text { Group n= } 34\end{array}$ & $\begin{array}{l}\text { Non-readmission } \\
\text { Group } n=76\end{array}$ & p \\
\hline Index LOS (days) & $8.1 \pm 5.7$ & $7.8 \pm 3.3$ & 0.76 \\
\hline \multirow{2}{*}{ LOS of readmission } & $8.3 \pm 6.2$ & & \\
\hline & $\mathrm{p}=0.92 *$ & & \\
\hline Cost analysis of index admission $(\$)$ & $794 \pm 908$ & $582 \pm 429$ & 0.20 \\
\hline \multirow[t]{2}{*}{ Cost analysis of readmission $(\$)$} & $1189 \pm 1491$ & & \\
\hline & $\mathrm{p}=0.35^{* *}$ & & \\
\hline $\begin{array}{l}\text { Data are presented as mean } \pm \text { SD. } \\
{ }^{*} \text { Comparison of index and second hospital } \\
{ }^{* *} \text { Comparison of index and second hospite }\end{array}$ & OS in the readr & $92)$ & \\
\hline
\end{tabular}

However, the difference between these two groups was not statistically significant $(p=0.76)$ (Table 3). Mean cost of second hospitalization was $\$ 1189$. Mean cost of index hospitalization of readmission group was $794 \$$ and that of non-readmission group was 582\$. However, the difference between these two groups was not statistically significant $(p=0.20)$ (Table 3).

\section{DISCUSSION}

There is an increasing concern about patients requiring readmission within 30 days after discharge from index hospitalization for AECOPD. Although about
$20 \%$ of patients hospitalized with AECOPD are re-hospitalized within 30 days, some differences regarding frequency of early readmission have been found. Reported rates of early readmission range from $8-26 \%(1-8)$. There is limited data regarding on all-cause readmission rate and risk factors at 30-day after discharge from hospital for AECOPD patients in the Turkish Society. In the current study, the early readmission rate in the first 30 days was $30 \%$ and is one of the highest values determined in the international literature. Reasons for the apparent discrepancy are likely multifactorial such as setting of investigation, patients baseline health conditions, complex- 
ity and characteristics of the patients (demographic, socio-cultural, geographic, economic), the post discharge environment, problems in the transition of care, different readmission strategies, etc. If the quality of care delivered in hospital loses its continuity after discharge, it may contribute to higher readmission rates. By the way, the majority of this cohort admitted to the hospital for a AECOPD received general care processes recommended by clinical practice guidelines. Implementing COPD guidelines is a necessary, but insufficient, step-in reducing readmissions and/or reducing health costs (9). A very comprehensive approach including post-discharge care plan, patient and family education and engagement in all decisions, assessment of comorbidities, patient self-management, inhaler device training, post-discharge early outpatient visit, home visit, telehealthcare, smoking cessation counseling, early pulmonary rehabilitation program may require to reduce to COPD readmission. However, care-of-transition factors and socioeconomic characteristics such as limited social support, lack of caregiver support at home, and financial troubles can also negatively affect post-discharge management (7). However, high 30-day readmission rates may present a major opportunity to advance quality of care and improve patient outcomes such as mortality and morbidity (2).

In the current study, only lower $\mathrm{FEV}_{1} \%$ and COPD diagnosis time were identified as risk factors. It was interesting to see that the diagnosis time of COPD was significantly lower in the readmision group. There may be deficiencies regarding self-management, education, treatment options and health insurance among COPD patients with lower diagnostic time. We also speculate that these patients are younger, may have more severe disease and may be frequent exacerbator. Already, the number of hospitalizations in the last year of the readmission group was found to be higher than that of non-readmission group (3.06 vs. 1.55, respectively). A few studies have also found that younger patients are at higher risk for readmission (10). The significance of $\mathrm{FEV}_{1}$ in predicting hospital admission for COPD is well recognized. As in the present study, if spirometry is performed in a clinically stable period, lower $\mathrm{FEV}_{1}$ values are associated with a higher risk of readmission. Thus, COPD patients with a low $\mathrm{FEV}_{1} \%$ were found to be at risk for readmission within 30 days of discharge from index hospitalization. Otherwise, a significant correlation between readmission and $\mathrm{FEV}_{1}$ may not be detected if the spirometry test is performed at dis- charge time (11). Guerrero et al. (12) have also found that lower $\mathrm{FEV}_{1}$ was an independent predictor of a new readmission within 30 days. Further, this study reported that the early readmission of AECOPD patients is associated with a progressive increase in the long-term risk of death. In the current study, readmitted patients scored slightly worse in only one SGRQ component: the overall impact on daily life and well-being (impact). Whereas, in one study, all three SGRQ components and the total score have been identified as independent predictors of readmission (11).

Some factors have also been reported as increasing risk for early readmission after AECOPD. The reported risks are comorbidities, male sex, age, low socioeconomic status, lower household income, previous exacerbations and hospitalizations, low BMI, physical inactivity, home oxygen use, elevated serum arterial blood carbondioxide level, prolonged length of stay, premature discharge from index admission, poor discharge medication, lack of family education on disease management, lack of communication with outpatient physicians, etc. $(2,6,13)$. A meta-analysis on 13 studies including a total of 3.792,506 patients have shown that comorbidities, previous exacerbations and hospitalizations, and increased length of initial hospital stay were the major risk factors for readmission at 30 days (14). Congestive heart failure, coronary disease, chronic cor pulmonale, lung cancer, diabetes, osteoporosis, frailty, psychiatric disorders such as depression, anxiety, alcohol and drug abuse are reported comorbidities regarding risk of early all-cause readmissions $(1,2,6,8,15,16)$. Congestive heart failure, renal failure, depression and alcohol use are associated with an increased risk of 30-day all-cause readmission in a meta-analysis (14). It has been reported that the risk may increase further, especially in the presence of multiple comorbidities (7). As in a few studies $(11,12)$, there was no significant relationship between re-admisison and comorbidities in the current study. This may be due to insufficient investigation and registration of all comorbidities.

In agreement with other published articles $(6,7,11,13)$, the current study observed that household income was slightly lower in the readmission group compared to non-readmitted ( $\$ 459$ vs. $\$ 537$, respective$\mid y$,$) . It is known that readmission is more common$ among socioeconomically disadvantaged communities. Lack of caregiver support at home may also make 
recovery difficult during posthospitalization periods due to increased emotional and physical stress (9). Hospitalizations constitute a very important part of the health care costs associated with COPD; however, readmission cost is also a very important part of this COPD healthcare cost. The costs of the readmitted within 30 days are relatively higher than those not readmitted $(4,6)$. In the current study, median cost was maximum at readmission followed by the index hospitalization of the readmission group and that of the non-readmission group $(\$ 1189, \$ 794, \$ 582$, respectively). It was seen that economic impact increased in this ranking. Despite the high rate of comorbidities, respiratory-based diseases were the most common reasons for readmission after discharge from hospital $(2,7,8)$. In the current study, the most common causes of readmission were primarily respiratory in nature. Length of stay (LOS), one of the health system related risk factors has been reported to be a significant risk factor for 30-day readmission. Readmitted patients usually have a longer index hospital stays $(2,6,8,11,13)$. A meta-analysis revealed that longer LOS was associated with increased risk of readmission (14). Some studies have also found patients with the shortest LOS were at higher risk than those who stayed slightly longer $(6,14)$. Prolonged LOS could reflect health status, both with respect to disease severity and/or social determinants of health (17). In the current study, the readmission group had slightly longer LOS than not readmitted ( 8.1 vs. 7.8 days, $p=0.76$ ). The average LOS was maximum in the rehospitalization, followed by the index hospitalization of readmission group. The variables including the use of NIMV, LTOT before index hospitalization were comparable between groups.

In a study, it has been found that readmitted patients used SABA, LABA, oxygen therapy and systemic corticosteroid significantly more than non-readmitted ones (1). In the current study, no significant difference was found between the groups on respiratory therapy (Table 2). Several studies have found that administration of dual corticosteroid and antibiotics therapy during the index stay or at discharge was significantly associated with a reduction in readmission $(6,18)$. Despite these results, it is known that not all COPD exacerbations are of bacterial origin and antibiotics are not required for all of them. It has also been reported that 30-day readmissions declined following the implementation of some COPD discharge care bundle programs (Hospital Readmission Reduction Program $=$ HRRP) which involve appropri- ate inhaler regimen, patient education regarding inhaler technique, follow-up within 15 days, standardized patient-centered discharge instructions $(19,22)$. Some studies have found that low physical activity is a risk for early readmission $(5,23)$. Pulmonary rehabilitation (PR) provided during or soon after a AECOPD is a highly effective and safe intervention to reduce the risk of hospitalizations (though not specifically 30-day readmission). PR initiated early (e.g. within 2-3 weeks) after AECOPD hospitalization reduce all- cause readmissions and mortality (24). It is difficult to determine the impact of pulmonary rehabilitation on early readmission, as the program is traditionally conducted over weeks or months (25). However, some discharge care bundle programs and quality care are not effective in reducing readmissions $(26,28)$. A systematic review has revealed that discharge care bundles for AECOPD led to fewer readmissions with no significant improvements in mortality and quality of life. Although various elements of discharge care bundles are used in different combinations in studies, it has been found that the most common interventions are demonstration of adequate inhaler technique, educational programs on self-management, individually tailored care plans for self-management, assessment and referral for pulmonary rehabilitation, outpatient follow-up and referral to a smoking cessation programs (29).

On the other hand, it is unclear whether reducing readmissions over 30 days correlates with improved patient health. Hearth failure (HF) is one of the most common causes of readmissions. A study examining the association between hospital 30-day readmission and mortality rates in patients with HF have raised concerns that 30-day low readmission rates can be accompanied by high mortality. It has been found that implementation of the HRRP was associated with a reduction in 30-day and 1-year risk-adjusted readmissions among patients with HF. However, HRRP was also associated with an increase in both short-term (30-day) and long-term (1-year) mortality (29). This may also be possible for COPD. High readmission rate can likewise be protective from mortality (8). Seemungal et al. (31) have reported that $25 \%$ of patients do not recover their lung function by day 35 after an AECOPD. Therefore, they may appropriately require rehospitalization during the naturally high-risk 30-day time interval (8).

The present analysis has some limitations, one of which is being a single center study. Although it 
reflects the results of a local area in the community, the center is a reference hospital, so patients are referred from various regions. Due to its single center and prospective features, the number of patients is limited and therefore its statistical power may be weakened. However, the inclusion of many risk factors in terms of early readmission in this study is also considered to be the advantage of the investigation.

In conclusion, this study showed that the frequency of readmissions within 30 days of discharge from index hospitalization for AECOPD were common and costly. Low FEV 1 percentage and lower COPD diagnosis time were found to be significant predictors for early readmission. Prediction of AECOPD patients with high risk of early readmission and prevention of rehospitalizations are important issues. In our society, it may be beneficial to monitor the rate of readmission, risk factors and cost with up-to-date analysis and studies. Identification of risk factors leading to readmission may contribute to the implementation of patient-centered strategies.

Ethical Committee Approval: This study was approved by the local institutional review board (Decision No: 369, Date: 03.01.2014).

\section{CONFLICT of INTEREST}

The authors of this meta-analysis declare that they have no conflict of interest.

\section{AUTHORSHIP CONTRIBUTIONS}

Concept/Design: CY, SÖ

Analysis/Interpretation: $\mathrm{CY}, \mathrm{SÖ}, \mathrm{OFE}$

Data acqusition: $\mathrm{CY}, \mathrm{SO}, \mathrm{OFE}$

Writing: $\mathrm{CY}$, SÖ

Clinical Revision: CY, SÖ, OFE

Final Approval: CY, SÖ, OFE

\section{REFERENCES}

1. Baker $\mathrm{CL}, \mathrm{Zou} \mathrm{KH}, \mathrm{Su}$ J. Risk assessment of readmissions following an initial COPD-related hospitalization. International Journal of COPD 2013; 8: 551-9.

2. Shah T, Valerie G, Press VG, Huisingh-Scheetz, White SR. COPD Readmissions Addressing COPD in the Era of Value-based Health Care. Chest 2016; 150: 916-26.

3. Spece $L J$, Donovan $L M$, Griffith $M F$, Margaret P. Collins, Laura C, Feemster L C, Au D H. Quality of Care Delivered to Veterans with COPD Exacerbation and the Association with 30-Day Readmission and Death. COPD: Journal of Chronic Obstructive Pulmonary Disease 2018; 15: 48995.
4. Crisafulli E, Ortega S, Torres A. Predictors of Readmission in a Period of 30 Days or Less in Acute Exacerbation of Chronic Obstructive Pulmonary Disease. Clin Pulm Med 2015; 22: 172-6.

5. Chawla H, Bulathsinghala C, Tejada J. P, Wakefield D, ZuWallack R. Physical Activity as a Predictor of Thirty-Day Hospital Readmission after a Discharge for a Clinical Exacerbation of Chronic Obstructive Pulmonary Disease. Annals of the American Thoracic Society 2014; 11: 12039.

6. Sharif R, Parekh T M, K S. Pierson K S, Kuo Y F, Sharma G. Predictors of early readmission among patients 40 to 64 years of age hospitalized for chronic obstructive pulmonary disease. Ann Am Thorac Soc 2014; 11: 685-94.

7. Jacobs D M, Noyes K, Zhao J, Gibson W, Murphy T F, Sethi $S$, Ochs-Balcom H M. Early hospital readmissions after an acute exacerbation of chronic obstructive pulmonary disease in the nationwide readmissions database. Ann Am Thorac Soc 2018; 15: 837-45.

8. Shah T, Churpek M, Perraillon M. C, Konetzka $R T$. Understanding Why Patients With COPD Get Readmitted. A Large National Study to Delineate the Medicare Population for the Readmissions Penalty Expansion. CHEST 2015; 147:1219-26.

9. Press V G, Au D H, Bourbeau J, Dransfield MT, Gershon A $S$ et al. Feemster $L C$; on behalf of the American Thoracic Society Behavioral Science and Health Services Research, Clinical Problems, and Nursing Assemblies. Reducing Chronic Obstructive Pulmonary Disease Hospital Readmissions. An Official American Thoracic Society Workshop Report. Ann Am Thorac Soc 2019; 16: 161-70.

10. Simmering JE, Polgreen LA, Comellas AP, et al. Identifying patients with \& COPD at high risk of readmission. Chronic Obstr Pulm Dis 2016; 3: 729-38.

11. Almagro P, Barreiro B Echagüen A O de, Quintana S, Carballeira M R, Heredia J LGarau J. Risk Factors for Hospital Readmission in Patients with Chronic Obstructive Pulmonary Disease. Respiration 2006; 73: 311-7.

12. Guerrero M, Crisafulli E, Liapikou A, Huerta A, Gabarrús $A$ et al. Readmission for Acute Exacerbation within 30 Days of Discharge Is Associated with a Subsequent Progressive Increase in Mortality Risk in COPD Patients: A Long-Term Observational Study. PLoS One 2016; 11(3): e0150737.

13. Lau CSM, Siracuse BL Chamberlain RS. Readmission after COPD exacerbation scale: determining 30-day readmission risk for COPD patients. International Journal of COPD 2017: 12; 1891-902.

14. Alqahtani JS, Njoku CM, Bereznicki B, Barbara C. Wimmer $B C$, Peterson GM et al. Risk factors for all-cause hospital readmission following exacerbation of COPD: a systematic review and meta-analysis. Eur Respir Rev 2020; 29: 190166.

15. Singh G, ZhangnW, KuonY-F, Sharma G. Association of Psychological Disorders With 30-Day Readmission Rates in Patients With COPD. CHEST 2016; 149(4): 905-15. 
16. Iyer A S, Bhatt S P, Garner I I, Wells I M, Trevor I L et al. Depression Is Associated with Readmission for Acute Exacerbation of Chronic Obstructive Pulmonary Disease. Annals ATS 2016; 13: 2.

17. Press VG, Konetzka RT, White SR. Insights about the Economic impact of COPD readmissions post implementation of the Hospital Readmission Reduction Program. Curr Opin Pulm Med 2018; 24(2): 138-46.

18. Stefan MS, Rothberg MB, Shieh M-S, Pekow PS, Lindenauer PK. Association Between Antibiotic Treatment and Outcomes in Patients Hospitalized With Acute Exacerbation of COPD Treated With Systemic Steroids. Chest 2013; 143; 82-90.

19. Zafar MA, Panos RJ, Ko J, Otten LC, Gentene $A$ et al. Reliable adherence to a COPD care bundle mitigates system-level failures and reduces COPD readmissions: a system redesign using improvement science. BMJ Quality \& Safety 2017; 26: 908-18.

20. Parikh R, Shah TG, Tandon R. COPD exacerbation care bundle improves standard of care, length of stay, and readmission rates. Int I Chron Obstruct Pulmon Dis 2016; 11: 577-83.

21. Ko FW, Ngai JC, Ng SS et al. COPD care programme can reduce readmissions and in-patient bed days. Respir Med 2014; 108: 1771-8.

22. Nguyen $H Q$, Chu L, Liu In-L A, Lee / S, Suh $D$ et al. Associations between physical activity and 30-day readmission risk in chronic obstructive pulmonary disease. Ann Am Thorac Soc 2014; 11: 695-705.

23. Puhan MA, Gimeno-Santos E, Scharplatz M, Troosters $T$, Walters EH, Steurer J. Pulmonary rehabilitation following exacerbations of chronic obstructive pulmonary disease. Cochrane Database Syst Rev 2011;10: CD005305.
24. Spruit MA, Singh S/, Garvey C, ZuWallack R, Nici L et al. An Official American Thoracic Society/European Respiratory Society statement: key concepts and advances in pulmonary rehabilitation. Am J Respir Crit Care Med 2013; 188: 13-64.

25. Jennings / $H$, Thavarajah K, Mendez M P, Eichenhorn M, Kvale P, Yessayan L. Predischarge bundle for patients with acute exacerbations of copd to reduce readmissions and ed visits. a randomized controlled trial. CHEST 2015; 147(5): 1227-34.

26. Adamson SL, Burns J, Camp PG, Sin DD, van Eeden SF. Impact of individualized care on readmissions after a hospitalization for acute exacerbation of COPD. International Journal of COPD 2016; 11: 61-71.

27. Bhatt S P, Wells J M, lyer A S, Kirkpatrick deN P, Parekh TM et al. Results of a Medicare Bundled Payments for Care Improvement Initiative for Chronic Obstructive Pulmonary Disease Readmissions. Ann Am Thorac Soc 2017; 14: 643-8.

28. Ospina MB, Mrklas K, Deuchar L, Rowe BH, Leigh R et al. A systematic review of the effectiveness of discharge care bundles for patients with COPD. Thorax 2017; 72: 31-9.

29. Gupta A, Allen LA, Bhatt DL, Cox M, DeVore $A D$ et al. Association of the Hospital Readmissions Reduction Program Implementation With Readmission and Mortality Outcomes in Heart Failure. JAMA Cardiol 2018; 3: 44-53.

30. Seemungal TA, Donaldson GC, Bhowmik A, Je ries DJ, Wedzicha JA. Time course and recovery of exacerba- tions in patients with chronic obstructive pulmonary disease. Am J Respir Crit Care Med 2000; 161: 1608-13. 